\title{
A TAKMILAH READING OF SPIRITUAL IMAGERY IN THE POEMS OF ABIZAI ABI
}

(Citra Kerohanian dalam Puisi Abizai Abi daripada Bacaan Takmilah)

Sakinah Abu Bakar

Sakinah57@yahoo.com

Helmi Yan

Universiti Sains Malaysia

Published online: 3 December 2018

To cite: Sakinah Abu Bakar dan Helmi Yan. (2018). A Takmilah reading of Spiritual Imagery in the Poems of Abizai Abi. Malay Literature 31(2), 332-360.

\begin{abstract}
This article focuses on a number of poems by Zainal Abidin Bin Haji Suhaili, better known as Abizai Abi, in his anthology of poems entitled Sinar Benar [True Ray of Light]. Abizai has been prolific in producing beautiful and meaningful poems of high quality. However, not many in-depth studies of his works have been conducted. This study attempts to examine several poems selected from Sinar Benar by employing the Takmilah Theory. Being an important writer in Malaysia, especially in the state of Sarawak, Abizai stands out through his application of spiritual imagery, in line with his framework of thought consistently anchored in the "relationship between human beings and Allah". This framework of thought encompasses issues of piety and obedience to Allah (SWT), which is entirely in line with the Takmilah Theory. This study finds that the beauty of Abizai Abi's poetry lies in its refined, meaningful and effective language. The poems studied also reveal that a good relationship between human beings and nature is the basis of a good relationship with the Great Creator. Abizai Abi's thinking is conveyed through the diction of his symbolism, which foregrounds "piety" and "utter humility". He
\end{abstract}


attempts to demystify nature and examine it spiritually, and relate it to the Greatness and Might of Allah (SWT) as the One who owns all.

Keywords: Abizai Abi, poems, Sinar Benar, Takmilah Theory

\begin{abstract}
Abstrak
Makalah ini memfokuskan penelitian terhadap sejumlah puisi Abizai Abi dalam kumpulan puisi perseorangan yang berjudul Sinar Benar. Abizai merupakan seorang penyair yang sangat produktif dalam menghasilkan puisi yang baik, indah dan bermakna. Namun begitu, tidak banyak kajian yang mendalam dilakukan terhadapnya. Kajian ini cuba menelusuri sejumlah puisi terpilih dari antologi puisinya berjudul Sinar Benar dari perspektif Teori Takmilah. Sesuai dengan kedudukannya sebagai penyair yang penting khususnya di Sarawak dan secara amnya di Malaysia, Abizai tampil dengan citra kerohanian daripada kerangka pemikirannya yang berlandaskan "hubungan manusia dengan Allah" secara konsisten. Kerangka pemikiran tersebut melampaui isu ketakwaan dan ketaatan manusia kepada Allah Azzawajjalla. Hal ini amat bertepatan dengan kecenderungan Teori Takmilah. Penelitian ini mendapati keindahan puisi Abizai Abi terpamer dari sudut bahasa yang diungkapkan dengan begitu halus, bermakna dan berkesan. Puisi tersebut juga menggambarkan hubungan baik sesama insan dan dengan alam sebagai landasan menjalin hubungan dengan Yang Maha Pencipta. Pemikiran Abizai Abi dititipkan melalui diksi perlambangan yang menyerlahkan makna "ketaatan" dan "kekerdilan diri". Beliau cuba menyingkap kejadian alam dan menelusurinya dengan mata hati untuk menghubungkannya dengan kebesaran dan kekuasaan Allah SWT sebagai pemilik segalagalanya.
\end{abstract}

Kata kunci: Abizai Abi, puisi, Sinar Benar, teori takmilah

\title{
INTRODUCTION
}

The late 20th century saw an encouraging number of writers and poets emerging in Sarawak. Several of these names are still active in Sarawak, and in the Malaysian poetry scene in general. According to the records of the "Hadiah Penghargaan Penulis Sarawak" [Sarawak Writer's Award], 55 poems by 33 writers have been on the winner's list between 1995 and 2006. In this period, Zainal Abidin Suhaili (Abizai Abi) has won the award a total of eight times, along other talented poets such as Jaafar Hamdan, Mohd.Taufek Saed, Sriwati Labot, Dahiri Saini, Roslan Jomel, Jais Sahok, 
Lawrence Atot, Latifah $\mathrm{Hj}$. Shelbi, Saie Dris, Pharo Abd.Hakim, Basri Abdillah, Adi Badiozaman Tuah and many more. ${ }^{1}$ This is an encouraging and laudable situation in the Malaysian poetry scene. ${ }^{2}$

Abizai Abi, who is a born Sarawakian, ${ }^{3}$ has produced six anthologies of his own poems, namely Seekor Kelawar di Kamar Pengantin [A Bat in the Bridal Bedchamber] (GPPS, 1989), Mengenal yang Asal [Recognizing the Original] (PUTERA, 2000), Membentuk Elok di Teluk Esok [Shaping the Beautiful in the Bay of Tomorrow] (DBP, 2001), Sang Kelawar Kesiangan [Bat At Daytime] (Citra Kurnia Enterprise, 2010), Sinar Benar [True Ray of Light] (DBP, 2011) and Kitab Rahsia [The Book of Secrets] (ITBM, 2015). Other anthologies in which his work was included alongside that of other poems are: Randau di Pulau, Dongeng Kembara [Island Dialogue, Travel Tales] (1990); Perkasihan Musim [Seasonal Love] (1992); Satu Perasmian [An Officiation] (1992); Simfoni dari Utara [Symphony from the North] (1994); Cetera '94 [The Story of '94] (1994); Menganyam Kedukaan [Weaving Sadness] (1997); Peta Seniman [The Map of the Artist] (1998); Gema Membelah Gema 12 [Echoes Dividing Echoes 12] (1990); Gema Membelah Gema 13 [Echoes Dividing Echoes 13] (1994); Gema Membelah Gema 14 [Echoes Dividing Echoes 14] (2004); Gema Membelah 15 [Echoes Dividing Echoes 15] (2007); Kota Asas Tamadun Bangsa [The Founding City of Our Civilization] (2002); Caturangga [Chessboard] (1999); Pelagus (2003); Wajah Kita [Our Faces] (2002); Nyanyian Pulau-pulau [Island Songs] (2004); Ratib Seribu Syair [Arrangement of a Thousand Poems] (2005); Antologi Sasterawan 2005 [Writers' Anthology 2005] (2005); Penangkap Rama-rama dan Kelawar [The Butterfly and Bat Catcher] (2005); Sejadah Hijrah [Prayer Mat of Migration] (2005); Belati Cinta Zulaikha [Zulaikha's Dagger of Love] (2004); Emas Tempawan [Wrought Gold] (2004); Alam yang Hijau [The Green Earth] (2007); Mengabdi Melestari [Serving and Sustaining] (2009); and Anak Global [Global Child] (2009). Abizai Abi is also very active in the Sarawak Writers' Association. ${ }^{4}$ Apart from writing poems, he also actively composes poetic songs and performs them with his group, Kelang-Kelus. He worked at the Miri branch of Bank Muamalat Malaysia Berhad for over 25 years. Currently, he operates a bookshop called Pustaka Akhbar in Miri, Sarawak.

Abizai Abi can be considered as Sarawak's most important contemporary poet. His name is frequently mentioned by literature enthusiasts, especially poetry lovers, in Malaysia. Although his poems have varying themes, they consistently adhere to his framework of "the relationship between humans 
and Allah". This framework of thought seeks to encompass issues concerning human piety to Allah (SWT). His attempts to realize the human relationship with the Great Creator through the depiction of virtue among people. Abizai Abi's thinking is conveyed through the diction of his symbolism whereby the meanings of "piety" and "utter humility" are emphasized, especially in Sinar Benar, an anthology comprising 123 of his poems.

\section{ABIZAI'S POEMS IN PREVIOUS STUDIES}

Abizai's poems have been studied by several local scholars, among them being Saiee Driss (1987), who examined Abizai Abi's anthology entitled Membentuk Elok di Teluk Esok. He found that the language of Abizai Abi's poems is poetic and contains symbolism, personification, metaphors, similes, hyperbole, anaphora and epistrophe. Ja'afar Haji Hamdan, in his article "Menekuni Imej Kelawar dalam Sinar Benar menerusi Nazrah Stilistik" ["Examining the Bat Image in Sinar Benar from a Stylistic Perspective"] in the language and literature column appearing in Utusan Borneo on 2 December, 2013, states among other things that the poems in Sinar Benar clarify the bat image that dominates much of Abizai Abi's work.

Sinar Benar, according to Ja'afar, is a collection that contains much philosophical thought, although only the bat imagery is discussed as a stylistic tool. It is clear that Abizai Abi is one of many poets who is capable of using "the best words in the best order". Therefore, each poem in Sinar Benar contains its own complex and challenging philosophy that require effort and close examination by the reader for understanding. Each contains a variety of meanings conveyed through the rhythms and rhymes of its language.

Apart from Saiee and Ja'afar, Nur Rassidah Utama has also done an analysis of the same anthology, in her article entitled "Mikrochiroptera dan Abizai: Satu Singkapan Ilmiah melalui Nazrah Semiotik" ["Microchiroptera and Abizai: An Academic Discussion from a Semiotics Perspective"] in the language and literature column of Utusan Borneo on 24 December 2012. Nur Rassidah selected only five poems from Sinar Benar (2011) that mention bats in their titles: "Penangkap Rama-Rama dan Kelawar" ["The Catcher of Butterflies and Bats"], "Bila Merak Bertukar Kelawar" ["When Peacocks Change Into Bats"], "Kelawar Kesiangan" ["Bats At Daytime"] (2), "Kelawar dan Sangkar" ["Bats and Cages"] and "Kelawar Yang Berlegar" ["Bats that Linger"]. This study suggests that the dominant bat symbol is used to express different meanings. The reader will encounter bat symbols that express negative meanings — changes in the lives of individuals and the wild 
desires of people who are sometimes worse than animals. Nur Rassidah also comes to the conclusion that Abizai Abi is a poet who highlights universal issues, which showcases his ability to make his poems expressions of human knowledge that are artistic and poetically idiosyncratic.

Sakinah, in her piece entitled "Puisi Sebagai Jalur Komunikasi: Meneroka Pemikiran Penyair Sarawak" ["Poems as a Communication Channel: Exploring the Thinking of Sarawakian Poets"], presented at the prize-giving ceremony of Dewan Bahasa dan Pustaka's writing and publishing award at the Balai Budaya of their Sarawak branch on 10 September, 2007, treats several poems by Abizai Abi that won "Hadiah Puisi Sarawak" [Sarawak Poetry Award]. Among these are "Penangkap Rama-Rama dan Kelawar", which is a narrative poem infused with imaginative elements that address both the personal and the universal. The narrative is enlivened by episodes in which the butterflies are put in jars, where they continue to live and become the bright ornaments of a colourful garden. Such a sight brings to life associations of the writer as an individual moved by subtle emotions, as shown in the lines aku yang melihatnyal tiba-tiba dihembus angin rial yang menggetarkan daun rasa ["I who see it/am suddenly blown by a happy breeze/that shakes the leaves of feeling"].

Another writer, Roslan Jomel, has written in his blog about Abizai Abi as an important contemporary Sarawakian poet. For Roslan Jomel, Abizai Abi is a poet who is well known for his refined language, and an individual who is humble yet fully aware of his own identity. In his dialogues with Roslan, Abizai Abi explained that bats represent people who have lost their glory, as well as people whose contributions are no longer appreciated and are forgotten by society. According to him, an important feature of harmony in Abizai Abi's poems are the metaphors that tie the poems together, and the nature images in them. The poet also does not have the tendency to use bombastic poetic expressions to shock his audience.

In an interview with Helmi Yan (conducted on 3 October, 2013, in Miri), Abizai Abi, explained that bats are unique animals. They are mysterious, often spending their lives sleeping during the day and hanging upside down; apart from this, they know the secrets of the caves that shelters them. Bats can thus be representative of the lives of people who are mysterious, alone and isolated.

A. Zainoor Ismail, in his article entitled "Sajak Berjiwa Islami" ["Poems of an Islamic Nature"] in Dewan Sastera magazine (retrieved from dunsastera.dbp.my on 2 May, 2014 at 11.00 a.m.), mentions several literature 
scholars who have commended the strength of Abizai Abi's poems from the perspective of language and presentation, especially his use of symbolism, personification, metaphor, simile, hyperbole, anaphora and epistrophe. $\mathrm{He}$ is said to be fond of poems with an Islamic or Sufi spirit, such as his poems "Sinar Benar" and "Aku Hanyalah Bayang-Bayang", which begin with a quotation from the Qur'anic, Surah al-Anfal, verse 17.

This can be seen to reflect the maturity and refinement of Abizai Abi's thinking reflected in the Islamic nature of the symbolism in his poetry. A. Zainoor Ismail is of the view that Abizai Abi wishes to make his readers realize that the value of a person lies not only in their external appearance. Furthermore, any beauty or greatness that a person possesses really belongs to Allah (SWT), for He is the Owner and Creator of all beauty and greatness.

A recent study by Abang Median Abang Said, entitled "Menelusuri Rahsia Takmilah dalam Kitab Rahsia" ["Tracing the Secrets of Takmilah in Kitab Rahsia"] and published in Utusan Borneo on 12 December 2016, discusses several poems from Kitab Rahsia (ITBM, 2015) using the principles of Shafie Abu Bakar's Takmilah Theory. According to this study, Abizai Abi is successful in infusing Islam in his way of life. The message expressed in his poems is firmly based in Islam. According to Abang Median, all the poems in Kitab Rahsia display Islam as the central pillar of identity through neat and well-developed ideas. The poems in Kitab Rahsia also place Abizai Abi among those poets who consider religion as the foundation and basis of their writing, with Islam at its root, in accordance with the Takmilah Theory.

Based on the brief survey of studies above, it is clear that Abizai Abi's poems demand careful attention because they present a thought whose framework is one of pure thinking, and in direct relation with the Almighty Creator, Allah (SWT). Such a treatment also allows a deeper study based on two elements of the Takmilah Theory, which is certain to ensure the continued benefit of knowledge contained in the following pages, especially in promoting the value of these poems in the world of Malaysian literature.

\section{TAKMILAH}

The term takmilah was first introduced by Shafie Abu Bakar in his paper entitled "Takmilah: Teori Sastera Islam" ["Takmilah: An Islamic Literary Theory"] at the Nadwah Sastera Islam Antarabangsa conference organized by Dewan Bahasa dan Pustaka (DBP) from 1 to 3 December, 1993. ${ }^{5}$ Takmilah is based on belief, which in turn is founded upon the concept of kesyumulan. Takmilah is developed based on this concept: all aspects of human life are 
confined within the sphere of tawhid (Oneness of Allah). The boundaries of tawhid form the parameters within which a work has meaning in the Takmilah theory. Literature, which has aesthetic elements, is not exempt from the boundaries of tawhid. The aspect of tawhid, which brings the concept of kesyumulan 6 to its pinnacle, is the basic philosophy behind the Takmilah Theory. Takmilah can be considered to be a universal theory encompassing all aspects of authorship within the Islamic mould. Takmilah requires that all parties in the literary sphere realize that literature, like all other fields in Islam, has a function to complete a Muslim writer's Islamic identity, which will reflect in the literary work produced. In other words, Takmilah is the completion of one's Islamic nature through literature.

Generally, the Takmilah Theory is holistic in nature and involves the relationship between human beings, here being the writer and audience, through the writer's work, with divinity, prophethood and knowledge. Seven principles are central to this theory: the principles that the Divine is kamal (perfect), that Prophet Muhammad is a being who is kamil (complete), and that Islam is akmal (more complete) ${ }^{7}$; the principle that knowledge and literature are takmilah (complementary) ${ }^{8}$; the principle that literature is aesthetic and takmilah (complete and complementary) in itself ${ }^{9}$; the principle that writers should perfect themselves ${ }^{10}$; and the principle that the audience should be encouraged to become insan kamil (perfect beings) ${ }^{11}$. On the whole, it can be said that it is difficult to find that special kind of poetry that when analysed contains all of these principles of the Takmilah Theory, with the exception of Sufi poetry.

The principle that the Divine is kamal (perfect) refers to the nature of Allah (SWT) Himself, whereas takmilah means "perfecting" or "complementary". This concept of perfection can be grasped when reading an interpretation of Surah al-Ghafir, verse 64, which can be interpreted as follows:

It is Allah who made for you the earth a place of settlement and the sky a ceiling and formed you and perfected your forms and provided you with good things. That is Allah, your Lord; then blessed is Allah, Lord of the worlds. ${ }^{12}$

Touching on the principle of prophethood and the prophet as insan kamil, Shafie explains that the Takmilah Theory considers Prophet Muhammad (SAW) as a perfect being, meaning that he is the most perfect human being according to Islamic philosophy, and that he embodies three ideals: 
insan kamil (the perfect being), insan khalifah (the Vicegerent) and insan Rabbani (a being of the Lord) (Dewan Sastera, 1996, p. 28). These three concepts are proven in the history of Islam, which tells about the life of Prophet Muhammad (SAW), where he was known as al-Amin (the trustworthy), al-Mustafa (the chosen one) and habibullah (the beloved of Allah). The Prophet (SAW) served concurrently as leader, administrator, judge and general. His outstanding talent in these fields was evident during the time his administration was centred in Madinah (Medina) and became a model administration for centuries to come. One of the reasons the Prophet (SAW) is held in high esteem by Muslims is that he was tasked, as Prophet and Messenger, with upholding the religious law first brought by Allah (SWT)'s Prophets and Messengers before him, as such making him the final Messenger of Allah (SWT) and the seal of the prophets. He was created by Allah (SWT) to be the best among the millions of people in this world. His uniqueness is acknowledged by Allah (SWT) Himself in Surah al-Qalam, verse 4, which can be interpreted as follows: "And indeed, you are of a great moral character. (68: 4).

Similarly, in Surah al-Ahzab, verse 21, Allah reiterates: "There has certainly been for you in the Messenger of Allah an excellent pattern ..." (33: 21)

\section{ANALYSIS AND DISCUSSION}

This article will now continue by focusing on selected poems from the anthology, Sinar Benar, by Abizai Abi using two of the seven principles of the Takmilah theory. ${ }^{13}$ The two principles are "The Principle of Perfect Divinity", which emphasizes tawhid and its relationship to the Perfection of Allah (SWT) and "The Principle of the Perfected Audience", which emphasizes the importance of producing poems that will leave an impression on the hearts of an audience. Through these selected poems, the attempt to include meaningful angles will be done in order to be beneficial to an audience.

\section{The Principle of Perfect Divinity: The Characteristic of Perfection}

The principle of the perfect Divine Being refers to the understanding that Allah (SWT) is kamal (perfect) in nature. This is emphasized in the Qur'an in Surah al-Baqarah, verse 163, whose meaning can be rendered as follows: 
And your god is one God. There is no deity [worthy of worship] except Him, the Entirely Merciful, the Especially Merciful.

This Qur'anic verse explains the Oneness of Allah (SWT) as His Nature. This is further explained in the same surah, verse 255 , whose meaning can be rendered as follows:

Allah - there is no deity except Him, the Ever-Living, the Sustainer of [all] existence. Neither drowsiness overtakes Him nor sleep. To Him belongs whatever is in the heavens and whatever is on the earth. Who is it that can intercede with Him except by His permission? He knows what is [presently] before them and what will be after them, and they encompass not a thing of His knowledge except for what He wills. His Kursi extends over the heavens and the earth, and their preservation tires Him not. And He is the Most High, the Most Great.

This point is emphasized in other verses, among them being Surah al-Baqarah, verse 284:

To Allah belongs whatever is in the heavens and whatever is in the earth. Whether you show what is within yourselves or conceal it, Allah will bring you to account for it. Then He will forgive whom He wills and punish whom He wills, and Allah is over all things competent.

Such is the perfection of Allah (SWT). Therefore human beings, as His creations, are merely weak and lowly creatures who have no other support or conviction other than what lies with Allah (SWT). The reality of faith is that the individual must have full conviction of something, in this case, full belief in Allah (SWT) and His beloved Prophet Muhammad (SAW). Faith is the will, desire and wish to follow the good human instinct that will ultimately benefit the self and others. Faith also means believing that human beings did not come to exist on their own without being permitted to exist by Allah (SWT). The true nur (light) of faith is tawfiq (success) and hidayah (guidance) from Allah (SWT) that is channelled through various sources of knowledge, inspiration, ladunni (divinely given knowledge), shahadah (profession of faith) and the like. Abizai, in his poem "Bacalah Kitab Rahsia" ["Read the Book of Secrets"] tries to explain the importance of understanding the truth of Divine Power through being insightful: 
Bacalah kitab rahsia

yang tiada berhuruf

yang tidak bertulis

tanpa bahasa perantara

tanpa persuratan bertinta
[Read the book of secrets

that is unlettered

that is unwritten

without language

without inked pages]

(Kitab Rahsia, 2015, p. 26)

Apart from this, this poem also tries to explain the existence of Allah (SWT) through repetition, whose meaning can be correctly grasped by the audience:

yang terawal tanpa bermula yang terakhir tanpa penghujung ... yang memberi tanpa bersebab...) [who is first without a beginning who is last without an end ... who gives without reason ...]

Allah (SWT) is the Most Generous and does not require any reciprocity from human beings, for whatever He awards them is for their own benefit. Every event has a hidden reason behind it that only $\mathrm{He}$ knows for $\mathrm{He}$ is All-Knowing.

Abizai Abi, through these stanzas, depicts the feelings of humility towards Allah (SWT) by His servant while admitting his dependence on Allah (SWT) through the expressions in his poems, such as the lines $A k u$ hanyalah bayang-bayang ["I am merely a shadow"], Aku hanyalah di buta ["I am only blinded"] and Aku cumalah sang alat ["I am merely a tool"], in the following poem:

Tanpa kehendak-Mu

tiadalah kehadiranku

tanpa kewujudanku

Kau tetap yang satu

Aku hanyalah bayang-bayang

tak mungkin mampu bergerak

tanpa tubuh-Mu yang bertindak

Aku hanyalah layang-layang

Tak mungkin dapat melayang

Tanpa talinya kau yang memegang ...
[Without Your Will

there would exist no me without my existence

You will still be the One

\section{I am merely a shadow}

not likely able to move

without Your body in action

I am merely a kite

not likely to fly

without You holding the string ... 


\section{Aku hanyalah di buta}

Yang melihat cahaya dengan mata-Mu

Aku hanyalah di pekak

Yang mendengar suara dengan telinga$\mathrm{Mu}$

Aku hanyalah anak patung

Yang merasakan hidup dalam sifat-Mu.

\section{Aku cumalah sang alat}

Yang kau berikan anak kunci

Untuk menari ligat

dan sering kali anak kunci itu patah dan sang alat kembali kaku

kerana ketetapan-Mu

tak mungkin berubah.

\section{I am only blinded}

Seeing the light with Your eyes

I am only deafened

Hearing sound with Your ears

I am only a doll

Who can live life in Your being

\section{I am merely a tool}

Which You have given a key

To do a wild dance

and often that key breaks

and the tool is still and stiff once

again

because what You command

will never change.]

(Abizai Abi, 2011, p.1)

In this poem, Abizai Abi stresses the majesty and power of Allah (SWT) as the Creator of the universe. Everything that exists on this earth is due to His Will. Allah (SWT) is the Possessor of everything, even without the presence of His servants. The next aspect that is emphasized on is the role of human beings as vicegerents who depend wholly on Allah (SWT) in their lives and that everything is according to the Will and Plan of Allah (SWT), who Most Powerful and the Most Perfect. Abizai Abi, with full conviction and faith in Allah (SWT), accepts that he is merely a servant of Allah (SWT) on this earth. Everything enjoyable is a gift from Allah (SWT). The feeling of humility is shown through the admission that all gifts - sight, hearing and feeling - that have been given are merely borrowed from Allah (SWT), the Most Generous and Most Exalted.

Faith lies in the belief that one's existence is merely because Allah (SWT) has permitted it. The true nur (light) of faith is tawfiq (success) and hidayah (guidance) from Allah (SWT) that is channelled through various sources of knowledge, inspiration, love and this earth, which is so rich in all kinds of pleasures and ways of life. It is precisely this meaning that Abizai Abi wishes to convey in each stanza of his poem, entitled "Doa (2)", and is presented in a submissive tone, (Abizai Abi, 2011, p. 105): 
Ya Allah yang zahir

Berikanlah aku minum

Segelas ikhlas yang jernih

Agar dahaga harapku hilang

Kepada apa sekali pun selain-Mu

Kurniakanlah aku pakaian

Daripada kain tawaduk

Agar aku sentiasa tunduk

Menginsafi kekerdilan diri

\section{Ya Allah Yang Batin}

Binalah aku ruang sabar

Untuk dapat tenang berteduh

Daripada lebat hujan cubaan-Mu

Jadikanlah aku seekor ikan cekal

Yang rela berenang

Di celah gelombang dan tenang

Lautan ciptaan-Mu.
O Allah, the Apparent

Give me to drink

A glass of clear sincerity

So that I may hope my thirst to go away

For anything other than You

Award me clothing

From the cloth of humilty

So that I will always bow

In realization of my own lowliness

O Allah the Unseen

Build for me a space of patience

As a calm shelter

From the torrential downpour of Your trials

Make me a hardy fish

Willing to swim

In the midst of the waves and calm

Of the ocean of Your creation.]

(Abizai Abi, 2011:24)

This poem also attempts to uncover the faith and piety that should be the basis of the lives of all of Allah (SWT)'s servants on this earth. The emphasis on the existence of Allah (SWT) and His Majesty is expressed in the lines of praise "Ya Allah yang Awal" ["O Allah, the Beginning"], "Ya Allah Yang Akhir" ["O Allah, the Last"], "Ya Allah yang Zahir" ["O Allah, the Apparent"] and "Ya Allah Yang Batin" ["O Allah, the Unseen"]. Abizai Abi, in "Doa (2)", supplicates to Allah (SWT) to always provide him with guidance so that he may always stay on the true path to Allah (SWT) and not go astray. He pleads that Allah (SWT) continue to give him guidance and direction in life, for he is afraid that he will go astray and commit sin. The poet also pleads for Allah (SWT) to continue granting him hidayah (guidance) and redha (contentment) in life. This poem showcases the fact that human beings are insignificant creatures beside Allah (SWT), the Most Powerful. It is a relationship that is fully understood and stems from love and adoration of God.

Abizai Abi again highlights the Greatness of Allah (SWT), the AllSeeing and All-Knowing of all that is on this earth. For example, in the 
poem "Sentiasa Memandang" ["Always Looking"], the poet reminds every human being who is considered vicegerent on earth to not feel lonely or alone, for as a servant, every one of them must be convinced that Allah (SWT) exists, sees all and knows all that happens on this earth. This is expressed in the following stanza:

\author{
Harus Kita \\ Tidak merasa sendirian \\ Sunyi daripada kehadiran \\ Kerana Dia sentiasa ada \\ Dan tetap memandang \\ Dengan mata \\ Yang tak pernah berkerdip \\ Sedetik pun.
}

[We must

Not feel alone

Lonely in existence

Because He is always there

And always looking

With eyes

That never blink

Even for a second.]

(Abizai Abi, 2011, p. 101)

An interpretation of what Allah (SWT) states in Surah an-Nur, verse 64 , is as follows:

Unquestionably, to Allah belongs whatever is in the heavens and earth. Already He knows that upon which you [stand] and [knows] the Day when they will be returned to Him and He will inform them of what they have done. And Allah is Knowing of all things.

The principle of Perfect Divinity can be identified as a theme and issue in Abizai Abi's poem "Sentiasa Kukenang" ["I always remember"]. Here, the poet tries to investigate the entirety of the love Allah (SWT) has for His servants. Allah (SWT), the Most Beneficent and the Most Merciful, has awarded every vicegerent with blessings and prosperity, whether they are thankful for it or not. This is expressed in the following stanza:

Hanya kepada yang sayang

Sentiasa kukenang

Yang maha penyayang

Dalam mengenang

Dengan menyusunjalinkan jalur

kemakmuran

Dan alur kesejahteraan

Di segenap kehidupan insan
[Only the one who loves

I always remember

The Most Loving

In remembrance

Arranging the warp and weft of wealth

And of welfare

In all human life 
Tanpa mengira diri-Nya

Dilupakan atau dikenang ...
Without caring whether $\mathrm{He}$

Is forgotten or remembered.]

(Abizai Abi, 2011, p. 105

Allah (SWT) showers His love in all manner of gifts for human beings to think and learn from, as well as being thankful for these for their own good. This is because everything belongs to Allah (SWT). He does not need the love of His creations; they are in need of His love.

The poem "Jernih" ["Clear"] below deals with the issue of repentance and realization, and returning to the true path:

Mencari wajah sendiri

Perlukan cermin yang jernih

Mencari wajah-Nya

Perlukan hati yang jernih

Lebih daripada segala cermin.

(Abizai Abi, 2011, p. 6)
[Looking for one's own face

Requires a clear mirror

Looking for His face

Requires a clear heart

More than any mirror.]

This poem also deals with the themes and issue of perfect divinity. Although the poem is very brief, with only two lines in the first stanza and three in the second stanza, its religious mission is evident. The poet wishes to remind himself and every other human being who wishes to come closer to Allah (SWT) to be completely truthful in their search. To know oneself, human beings need to first have a clear heart - a heart full of honesty and tawadhu' (humility, humbleness) - and submit to Him. Therefore, understanding one's own insignificance as a being will bring one to be in awe of Allah (SWT), the All-Powerful. Moreover, in order to know Allah (SWT), human beings must accept and submit to His qada (divine decree) and qadar (predestination) honestly, truthfully, and full of realization, as well as making a genuine effort to not stray from making Allah (SWT) their only goal.

The poem "Harus Ada Dia" ["He Must Be There"] deals with the existence and power of Allah (SWT). Human beings at times fail to use their mental faculties fully and often do not realize that they are surrounded by signs of Allah (SWT)'s Greatness; such signs include plants, animals and natural phenomena such as earthquakes, typhoons, floods, lightning, 
rain, solar eclipses, volcanoes and the like. Apart from this, Allah (SWT) also reminds His servants of the signs of His Greatness and existence. Only those who ponder are able to recognize these as evident or hidden signs of Allah (SWT)'s power. The closest proof of His existence that human beings always forget is themselves. This is what Abizai Abi attempts to express in the following poem:

Sebelum bunga berpucuk

Harus ada Dia

Yang kau lihat menyemaikan benih

Di ruang taman

Ketika matahari terjaga

Harus ada Dia

Yang kaupandang memerangkap siang

Di kaki hari

Selepas musim hujan

Harus ada Dia

Yang kaunampak membasahkan daun

Di perdu pohon.

(Abizai Abi, 2011, p. 33)
[Before the flower blossoms

There must be Him

Who sees you sowing the seed

In your garden

When the sun awakens

There must be Him

That you see catching daytime

At the foot of day

After the rainy season

There must be Him

That you see watering the leaves

On the tree trunks.]

The poet tries to get people to think and ponder on natural phenomena that is entirely the result of Allah (SWT)'s power. Abizai Abi reminds human beings that nature, such as flowers that grow and bloom and the sun that rises in the morning, exists only because their Creator, Allah (SWT), has willed it, just as he commands the rain to fall on earth and make the ground fertile- everything is due to the power of Allah (SWT). Everything that exists on this earth is because of His power. The fact that Allah (SWT) is in command of the entire world is also seen in another poem by Abizai Abi, "Rahsia Berselubung (2)" ["The Covered Secret (2)"], from his anthology Sinar Benar:

Tersembunyi Dia

Pada setiap sesuatu

Ada tetapi tiada berupa
[He is hidden

In each and everything

Existing but without form 
Tiada di alam mata

Nyata di dunia rasa

Berbeza Dia

Daripada setiap sesuatu

Tiada berkerdip di langit bayangan

Tiada beriak di kolam gambaran

Rahsia berselubung penuh

Seperti kemisterian roh

Hanya ternganga pintu guanya

Kepada insan yang kenal hakikat diri

Dan zat yang wajib wujud.

(Abizai Abi, 2011, p. 114).
Not in the visible world

Evident in the world of feeling

He is different

From each and everything

Not blinking in an imagined sky

Not rippling in a pictured pond

A mystery completely covered

Like the mystery of the soul

The entrance to its cave is only open

To those beings who recognize

themselves

And the substance that must exist.]

The principle of perfect divinity is very clear. These lines clearly depict the writer's thoughts as he tries to uncover Allah (SWT)'s existence in everything that exists on this earth; His existence cannot be seen but can only be felt through faith and a clear soul. The poet also reminds all human beings that nothing exists on this earth that is like Allah (SWT). This is the mystery and secret of Allah (SWT); only His servants who have complete conviction and acknowledge His Greatness will feel that Allah (SWT) is always with them in all situations.

\section{The Principle of the Perfected Audience}

Human beings are creatures with a soul; that is they have emotions and a conscience. Physically, they are capable of standing on their own two feet but circumstances in their lives may weaken their soul before they are able to enter the place of glory. Its glory is far beyond anything in the physical world where human beings live. After all the worldly pursuits and ambitions have weakened them, the main task of human beings in sailing the sea of life is to recover their lost identity so that their own soul's cries and screams can be silenced with the light of the soul that shines brightly around every being. The principle of the perfected audience can be traced in several of Abizai Abi's poems. Islam continuously calls upon its followers to do good and to do so honestly, in the hopes of gaining Allah (SWT)'s pleasure.

Abizai Abi chooses to make his poems as vessels to convey religion to his audience, to remind them that worldly pursuits mostly leads to negligence 
and destruction. This is expressed clearly in his poem, "Selamat Datang ke Kota Impian" ["Welcome to the City of Dreams"].

Selamat datang ke Kota Impian

Segalanya ada di sini

Keretapi kemajuan yang tak pernah menunggu

Jika kau leka menangguhkan waktu

Lambaian gadis cantik dan berani

Mampu mematahkan jeriji sepi

Pusat hiburan yang tak kunjung

kantuk

Menyajikan santapan khayal beribu liku.

Selamat datang ke kota impian

Segalanya ada di sini

Jika hati mudah dipeluk goda

Kota ini akan menjadi musuh utama

Menolakmu jatuh ke lembah dosa

Jika tidak berkocak di dalam kalbu

Kota ini menjelma sebagai sahabat setia

Menyediakan lorong yang panjang

Buat mengutip mutiara rahmat

Dan zamrud nikmat kurniaan-Nya.
[Welcome to the City of Dreams

Everything is here

The train of progress that never waits If you are remiss when it comes to time

Daring, pretty girls that wave Are able to break the bars of loneliness

The never-tired entertainment spots Provide visions of a thousand choices.

Welcome to the city of dreams Everything is here If the heart is easily embraced by temptation

This city will be the worst enemy Pushing you into the valley of sin If your inner self is not rattled This city will appear as your best friend

Showing you a long path To pick up pearls of mercy And emeralds of His blessings.]

(Abizai Abi, 2011, p. 31)

In these lines, the poet depicts the people in a city. This world is merely a changeable stage, depending on the way of life a person chooses. The city promises a life that is filled with a thousand and one pleasures. Progress and ease are corrupting forces, and beautiful women can tempt one to a valley of sin and depravity. The poet also reminds that people must stock up on good deeds to build a wall of faith, for without it, they will easily fall into the valley of destruction. Therefore, Abizai Abi emphasizes that human beings who have faith and conviction will not easily be led astray and will not be tempted by sin. The world will be more meaningful as a place for collecting good deeds in preparation for the afterlife. 
In his poem, "Berkecailah Segala Kaca Fana" ["Shattered will be the Mortal Glass"], Abizai Abi deals with the lives of human beings in this transient world as travellers who must fulfil their tasks as servants, after which they will return to the place of their origin, the eternal world:

Asal tanah kembali ke tanah
asal air kembali ke air
asal api kembali ke api
asal angin kembali ke angin
Asal kata kembali ke nokhtah
asal pohon kembali ke benih
asal hujung kembali ke pangkal
asal hilir kembali ke hulu

Berkecailah segala kaca fana Berkekalan zat yang baka.

\section{Satu hanya}

Yang wajib wujud Dia.

\begin{abstract}
[What was earth will again be earth what was water will again be water what was fire will again be fire what was wind will again be wind
\end{abstract}

What was a word will return to be a dot what was a tree will return to being a seed what was an end will return to the beginning what was downstream will return upstream

Shattered will be the mortal glass Lasting will be the eternal substance.

Only One

Must exist: He.]

(Abizai Abi, 2011, p. 120).

The most interesting feature of this poem is the repetition in the first two stanzas, which provides a strong rhythmic effect. Similarly, the juxtaposition of berkecailah [shattered] and berkekalan [lasting] provides a meaningful opposition. All falsehood is destroyed and what remains is only truth. When examined superficially, the poem seems easy enough to understand. However, when analysed in detail, it becomes clear that the poet presents a fact that needs careful consideration, which is about the origin of His creation. The title of this poem also suggests the destruction of this world and the continued existence of the afterworld to which every creation must return.

Islam always calls on its followers to perform charity or do good with honest intentions in order to gain the pleasure of Allah (SWT). In performing a deed of charity, every Muslim should possess a sense of humility before Allah (SWT), because He knows our innermost thoughts and intentions. When someone performs a good deed merely to be acknowledged and praised by others, they are considered hypocritical and arrogant. Allah (SWT) says in Surah al-Ma'un: So woe to those who pray. But] who are heedless of 
their prayer. Those who make show [of their deeds]. And withhold [simple] assistance. (107: 4-7).

The above verse refers to hypocrites who boast about their prayer before other believers. However, when there are no believers with them, they abandon their prayer. Such people are remiss of their prayers and of prayer times. If one does something solely to obtain the praise or fame of other people, it is mere arrogance and this is something that does not please Allah (SWT). This also includes people who refuse to pay zakat (poor tax).

Further, Abizai Abi reminds his audience whence they came and to where they shall return. The nature of human beings is that they have hypocritical tendencies, which prevents them from living the life promoted by Islam, even though Allah (SWT) has given them much by way of bounty, and of which they are to share a part with those who need them, according to what has been prescribed in the Qur'an by Allah (SWT), and reiterated in the hadith of Prophet Muhammad (SAW). All the bounty awarded by Allah (SWT) to human beings is to be used beneficially in order to receive the rewards of the hereafter. This is because this world is merely transient while the Nature and Power of Allah (SWT) is everlasting: "...Berkecailah segala kaca fana/ Berkekalan zat yang baka/ Satu hanya/Yang wajib wujud Dia" ["Shattered will be the mortal glass/Lasting will be the eternal substance./ Only One/Must exist: He."].

It is evident that the poem is intended to inject in the self and the readership the realization of the need to become a better human being. A good work of literature is one that is in line with the Islamic Weltanschauungone that calls upon human beings to do good and is capable of influencing and changing its readership to come forth as true Muslims, and be able to lead their lives in line with the requirements of Islam. Such a work is aimed at creating insan kamil, or people who model their character on that of Prophet Muhammad (SAW). In regard to this, Abizai Abi consciously makes his poems as the vehicle for such a message but he does so with personal humility.

Abizai Abi uses poetry as the medium for spreading a particular message to his audience, calling on them to make an effort to model themselves on insan kamil. In the poem "Riak" ["Arrogance"], Abizai Abi imparts spiritual values by showing the obvious falseness and pretence that rules the hearts of those who compete to do good deeds. On the other hand, those who are insensitive and engrossed with their own matters will fail to recognize the falseness that surrounds them. Finally, the poet reminds the audience to be careful and not to allow falseness to take root in their hearts. They will be 
at a true loss if they do not perform good deeds because every good deed will receive its reward and will be blessed by Allah (SWT). However, if every good deed is performed merely for pride and arrogance, it will be useless and even become a sinful act. This is expressed by the poet in the following stanzas:

\section{Nanah Nafsu \\ Yang tumbuh di tubuh maksiat \\ Kelihatan jelas}

Bakteria serakah

Yang tersembunyi di balik ibadat

Sangat berahsia

Awasilah benihnya

Bercambah diam jauh di dalam

Pucuk yang sepatutnya menjadi pohon suci

Membesar sebagai dedalu dosa.

(Abizai Abi, 2011, p. 87).
[The pus of desire

Growing on the body of $\sin$

Shows clearly

The bacteria of avarice

That hides behind worship

Hides in deep secrecy

Beware its seed

That sprouts deep inside

The shoots that should become the holy tree

Will grow into the thorny parasites of $\sin$.]

Abizai Abi, as a spiritual poet, continuously writes poems that are capable of becoming vessels and guides for his audience. Human beings will only develop realization when their heart is open to it. They ought to not only look at something with their sight but also with insight. Insight is the best kind of sight because it sees that which lies behind what is evident. Insight can see through the outward and into the inward, and is capable of differentiating the real from the illusory. Allah (SWT) says in the Qur'an, in Surah al-Haj, verse 46:

So have they not travelled through the earth and have hearts by which to reason and ears by which to hear? For indeed, it is not eyes that are blinded, but blinded are the hearts which are within the breasts.

Another poem by Abizai Abi that clearly calls upon human beings to better themselves is Lalat di dalam solat [Flies during prayer], which deals with the concept of khushu' [humility] — full devotion — during prayer, as prayer is a pillar of faith. Khushu' is a requirement that determines whether or not one's prayer is accepted by Allah (SWT). If one does not fulfil this 
requirement while in prayer, the emptiness will be filled with carelessness or negligence. Abizai Abi expresses this in the poem as follows:

Ketika mengharungi lautan solat

Kaucari pulau khusyuk yang teduh

Namun ribuan lalat mula hinggap di layar ingatan

Membawamu sesat di selat khayalan Jangan kauharap akan berjumpa Selagi keakuanmu tidak kaubuangkan...
[While riding the waves of the ocean of prayer

You look for the shady island of humility

But thousands of flies begin to land on the sail of your thoughts Leading you to stray on the strait of fantasy

Do not hope to find your way

(Abizai Abi, 2011). Until you rid yourself of your egotism ...]

Those who are negligent will not be able to experience the Majesty of Allah (SWT), even if their tongues speak the words that praise Him a thousandfold. Negligence in prayer is compared to flies. Flies connote the disgusting and dirty, and in this poem the "flies" are depicted as sticking to the sail of thought, or imagination that disturbs one's concentration and devotion in prayer. This is a common experience for most people, as full concentration in prayer, and thus humility, is difficult to achieve. A more interesting point in the poem above is the reminder concerning egotism. While prostrating in prayer, one should do so as a servant to his Lord, Allah (SWT) the All-Powerful, and prostrate in complete humbleness and submission, in order to experience complete humility. In this fashion, all manner of human arrogance should be whittled away to face the Lord of the Worlds.

... Jangan kauharap akan bertemu

Selagi tidak kaubersihkan bahtera kalbumu

Yang penuh dengan najis cemburu

Yang sarat dengan nanah amarah

Yang berat dengan sampah dendam

Yang pekat dengan lendir berahi

Sarang membiak zuriat maksiat

Hasil permukahan nafsu dan syaitan...

(Abizai Abi, 2011, p. 4)
[... Do not hope to be able to meet Him

If you have not cleansed the ship of your soul

Which is filled with the filth of envy Which is loaded with the pus of fury Which is heavy with the refuse of revenge

Which is thick with the mucus of sexual passion

A nest that breeds the brood of vice

Out of an adulterous union between lust and Satan ...] 
Evidently, the poet uses his poem as a vessel for the religious message of calling human beings to follow the example of insan kamil (perfect being). To achieve a higher level of virtue, human beings are encouraged to remove all negative characteristics, depicted through disgusting and even frightening images such as najis cemburu [filth of envy], nanah amarah [pus of fury], sampah dendam [refuse of revenge], lendir berahi [mucus of sexual passion] and zuriat maksiat [brood of vice].

The poem "Terkulai Mabuk Ketagih Serbuk" ["Intoxicated Limp Addict to Powder"] can also be seen as stemming from the poet's thoughts on leading his audience towards becoming insan kamil. The poet seeks to convey to society the message that social problems are capable of ruining and leading astray the human beings who live on Allah (SWT)'s earth, especially in this new millennium. The main theme of this poem is the issue of drug addiction in society, especially among Muslims. Drug abuse is one of the critical social issues, especially among Muslims, and is a great problem in the country. Some of the lines of the poem read as follows:

... Ramai orang menghirupnya

kerana ingin sampai ke syurga

khayalan

yang kononnya mampu melenyapkan

sebentar

sengsara hidup di alam benar...

... Jangan kauhirup madu bertuba itu

kerana manisnya akan segera hilang

bisa racunnya pasti merayap

berpanjangan

menjadi musuh di dalam pembuluh

dalam diam perlahan-lahan

membunuh...

(Abizai Abi, 2011, p. 82)
[Many people take it to get to the paradise of hallucination which supposedly can extinguish for a moment

the torture of this real world ...

... Don't sip this poisonous honey for its sweetness will soon disappear the sting of its poison will continue to creep and become an enemy in your veins killing you slowly and quietly ...]

The poet sharply criticizes youngsters who are involved in drug addiction. These youngsters believe that by taking drugs, they will enter a fantasy world that will make them forget the problems that they face in the real world. They take drugs as if it were a favourite food, as if there is nothing better than the hallucinations that they experience when they are high on drugs. In the poem, the poet calls on youngsters to be united in avoiding 
drugs, and prevent spreading the drug problem further as drug abuse leads to other social problems. The poet hopes that all members of society ensure that teenagers and young people are given a thorough religious education, and provide society with a spark of hope through emphasizing religion and developing the nation.

That Abizai Abi often calls on his readers to be pious and strive for a virtuous life in this world cannot be denied. Poems are the battlefield of Abizai Abi's jihad [struggle]; they are used to invite his audience to return and get closer to Allah (SWT) in order to gain His pleasure. "Kembalilah ke Perdu Akar" ["Return to the Cluster of Roots"] is one example of this:

Setelah menjadi ranting dan mencapai awan tinggi hingga menikmati sinar mentari janganlah kaulupakan diri.

sesekali kembalilah ke perdu akar yang memungkinkan kaujauh menjalar.

\author{
[After becoming a branch \\ And reaching the high clouds \\ to enjoy the bright sunlight \\ do not forget yourself. \\ once in a while, return to the \\ cluster of roots \\ that have enabled you to creep far.]
}

(Abizai Abi, 2011, p. 110).

Although the above poem is brief and direct, it has a very deep meaning when analysed closely. To Abizai Abi, all human beings are Allah (SWT)'s vicegerents on earth and they should not forget their origin. No matter how great the success one has achieved or how far one has travelled, one must return to remembering Allah (SWT) as the Giver of all blessings and subsistence to His servants. Everything happens with His permission. The same message can be discerned in "Hujan (4)" ["Rain (4)"] where it is expressed in the following way:

Sekali kau disimbah hujan

Seluruh hatimu bergetaran

Merasakan kehadiran

Titisan jernih

Dari langit ke tujuh

Meresap menyentuh

Sehingga kaulupa jelita dunia

Yang sering kaupuja

Sehingga lenyap kerdipan harta

Yang sentiasa muncul di mata.
[Once you have been drenched by rain Your entire heart vibrates

Feeling the presence

Clear drops

From the seventh heaven

Absorb and touch

Until you forget the beauties of this world

That you often worship

Until the sparkle of riches disappears That always appears to the eyes. 
Sekali kau disimbah hujan

Sepenuh jiwamu tenang

menikmati suci kasih sayang.

(Abizai Abi, 2011, p. 115).
Once you have been drenched by rain

Your soul is completely calm

enjoying the pure love.]

The word "hujan" [rain] here carries a connotation far bigger than its literal meaning. Rain is clear drops of water that are a gift from God. The water itself comes from a source that cannot be fathomed by human beings. These clear drops can be interpreted as either retribution or reward, both of which have their own blessing. People are usually thankful when they are rewarded, while they tend to lose direction when they receive divine retribution. Human thinking is slow to understand the function or wisdom behind any phenomenon. Just as the other poems selected in this article, these poems also succeed in creating an audience who are aware of their condition of abject humbleness and insignificance against the Power of the Almighty Creator. However, the uniqueness of the poems lies in the figurative use of nature and the special characteristic of water as it is created, which leads back to the Wise, Almighty Creator. Abizai Abi fulfils his mission of religious da'wah [propagation] through his poetry, in line with the Takmilah Theory, which aims to call and encourage human beings to become insan kamil.

"Sinar Benar" is truly a pure expression stemming from a clear heart. No effort is more honourable than that of lips expressing the word of Allah (SWT), and glorifying Him. No effort is greater than encouraging human beings to acknowledge the truth of His Power. Abizai Abi expresses this through his poems using simple language and a soft tone, even though there is a note of emphasis. In one poem, Abizai Abi emphasizes his own insignificance:

... dan aku sebagai penyajak cumalah bayang-bayang kepada kehendak dan gerak pemilik segala keindahan ... $[\ldots$ and $\mathrm{I}$ as a poet am merely a shadow to the will and actions of the Owner of all beauty...]

(Abizai Abi, 2011).

The poet admits that the further he uncovers the secrets of creation, the more he will discover that it shows the Majesty of Allah (SWT) as the 
One who possesses all things. As a poet, the writer understands that he is merely a shadow created by Allah (SWT), who owns everything and who has the power to create everything that will happen to His servants. Abizai Abi's deep interest in the Sufi poetry of Jalaluddin Rumi, Fariduddin Attar, Ibn Arabi, Sa'di and Hamzah Fansuri is clearly not in vain. In his obsession with refinement and clarity of emotion expressed in beautiful language and meaning, the poet finally realizes and understands that beauty-whether in terms of form, voice, language, and all types of exterior beauty-is in reality only a shadow that allows human beings to learn to recognize love, humble themselves and glorify Allah (SWT), the Possessor of all beauty.

\section{CONCLUSION}

Based on the poems under analysis here, it is found that Abizai Abi is a poet who emphasizes spirituality by clarifying belief, submission and the quest to obtain God's pleasure. Apart from this, his poems also encourage readers to adopt the honourable characteristics of insan kamil, as manifested by Prophet Muhammad (SAW). This can be linked to his effort to make his audience use the honourable characteristics as a model to get closer to being insan kamil themselves.

The principle of perfect divinity concerns Allah (SWT)'s characteristics as kamal [perfect]. The perfection of Allah (SWT) is displayed not only in the visual perception observable with the naked eye of the poet, but also through his insight. The poet's insight is guided by his will to convey a religious message through the beautiful diction of his lines, which are at once poetic and, more so, meaningful. It is truly as Allah (SWT) has said, that His power is beyond heaven and earth, and encompasses what is in people's hearts. Human perception is extremely limited, a drop of ink in a vast ocean of meaning that cannot be grasped by insignificant human beings. Therefore, sharing Abizai Abi's deep thoughts on the insignificance of human beings as compared to the power of Allah (SWT) and His perfection can be of benefit to an audience, like a very precious pearl.

The poems discussed here using the principle of perfected audience encourages the audience to become insan kamil, and provide a more detailed interpretation of the responsibility of Muslims in calling others to do good. Through this principle, the ideas contained in these poems can be further appreciated in detail. Both the principles that have been selected from the Takmilah Theory as a framework are dominant, as they are based on tawhid, which explains a vertical relationship between human beings and Allah (SWT) as well as a horizontal one between human beings and nature. 


\section{NOTES}

1 The Hadiah Penghargaan Penulis Sarawak [Sarawak Writers Appreciation Award] has been won by Abizai Abi as many as eight times, followed by Jaafar Hamdan who has won it four times; it has also been won by Mohd. Taufek Mohd. Saed and Sriwati Labot three times each; Arjuna Mustapha, Abg. Kassim Abg. Bujang, Dahiri Saini, Suhai Ragas, Hipani Alwi, Ummy Hafiza Mahri, Jais Sahok and Roslan Jomel twice each; and by Rosani Hiplee, Lawrence Atot, Kiprawi Sani, Piee Ling, Latiffah $\mathrm{Hj}$. Morshidi, Yahya Mat, Zainudin Lokman, Latifah Hj. Shebli, Desmond Manja Gasan, Saie Dris, Suhaili Ghani, Bibi Sabariah Haji Abang Awet, Awang Kelana, Pharo Abd. Hakim, Abdillah Untong, Yusof Lotot, Basri Abdillah, Norsari Hj.Abdul Hadi, Sazali Moshidi, Adi Badiozaman Tuah and Maslina Mahbu once each. This development is a benchmark in poetry writing in Sarawak.

2 Sakinah Abu Bakar. "Puisi Sebagai Jalur Komunikasi: Meneroka Pemikiran Penyair Sarawak" ["Poetry as a Communication Channel: Exploring the Thinking of Sarawakian Poets"]. Paper presented at the Balai Budaya of the Sarawak Branch of Dewan Bahasa dan Pustaka on 10 September, 2007, in conjunction with the prizegiving ceremony of the Writers' and Publisher's Award.

3 Abizai Abi is the nom de plume of Zainal Abidin Haji Suhaili. He was born in Kuching, Sarawak, on 19 September, 1966 and received his education up until SPM level at SMK Dato Permaisuri secondary school in Miri. He later obtained a diploma in Sports Management and an honours degree in literature from the University Sains Malaysia (USM) in 2012. He began writing poetry, short stories and literary criticism in the early 1980s. His writings have been published in various newspapers and magazines in the country; examples include Pelita Minggu, Mingguan Malaysia, Dewan Sastera, Pelita Bahasa, Utusan Sarawak, The Borneo Post, Malay Literature and others.

$4 \mathrm{He}$ is active in the North Sarawak Writer's Association (PUTERA), in which he currently holds a leadership position. He was also the winner of Hadiah Penghargaan Penulis Sarawak [Sarawak Writers Appreciation Award] for poetry in 1991, 1995, 1996, 1997, 1998, 1999, 2000, 2003, 2005, 2006, 2007, 2008, 2009 and 2010; awarded the Sarawak Literature Award for critical essays in 2011; awarded the first prize in Hadiah Galakan Sastera Kenyalang [Hornbill Literature Encouragement Award] for poetry in 1993/1994; awarded third prize in Peraduan Menulis Puisi Anti-dadah [Antidrug Poetry-writing Competition] 1994; awarded third prize in Peraduan Menulis Puisi Bulan Bahasa [Language Month Poetry Competition] 1997; awarded Hadiah Sastera Kebangsaan Negeri Sarawak [National Literature Prize for Sarawak] (poetry genre) by the state government of Sarawak in 1997; awarded Hadiah Sastera Perdana Malaysia [Malaysia Premier Literature Award] 2000/2001 for his poetry anthology entitled Membentuk Elok di Teluk Esok; awarded the consolation prize in the poetry category, Hadiah Sastera Kumpulan Utusan [Utusan Group Literature Award] in 2003 and 2007; awarded the consolation prize for Islamic Literature in 2005; awarded the consolation prize for Consumer Poetry in 2006; awarded Hadiah Sastera Perdana Malaysia [Malaysia Premier Literature Award] 2006-2007; and awarded Hadiah Sastera Perdana Malaysia [Malaysia Premier Literature Award] 2008-2009. He also represented Malaysia in the MASTERA writing programme in Bogor, Indonesia, in August 2002. His poem, entitled "Kembali Gawai Rindu Terlerai" ["Thanksgiving Returns and the Longing is Stilled"], was selected as a school literature text beginning in 2010. 


\section{MALAY LITERATURE VOLUME 31 NUMBER 2 DECEMBER 2018}

5 To strengthen Takmilah as a literary theory that can be used for successful analysis in literary criticism, it was first applied on an analysis of the anthology of poetry entitled Kau dan Aku [You and Me] by A. Aziz Deraman and presented at a book discussion in conjunction with Literature Week 1994 at Dewan Bahasa dan Pustaka.

6 From the root word "syumul" a loan word from Arabic meaning comprehensive or universal.

7 Through the third principle of the Takmilah Theory, Shafie Abu Bakar (1996:26) explains that Islam is a complete religion that is capable of perfecting all aspects of human life, including the literary aspect. The work that is thus produced can play a role in encouraging the individual and the whole of society to practice the teachings of Islam. Ideally, Islam is not only concerned with the concept of faith but also its practices and all its laws.

8 The concept of Takmilah can be seen in the relationship between literature and knowledge that has links with the individual's faculties, particularly the mind and the heart. In Islam, the mind is accepted as the main tool to achieve knowledge. Literary works are considered in Islam not only as a form of entertainment but also of didacticism; more importantly, they are not meant to merely pass time but should educate and remind of the Greatness of Allah (SWT).

9 According to Shafie Abu Bakar (1996, pp. 29-30), this principle can be viewed from two aspects of external beauty and one of beauty of meaning. The external aspects of beauty concern technique, form, structure and style whereas the beauty of meaning refers to the message, thought, point of view and philosophy that it contains. He iterates that this principle leads to a process and development of literature that is creative, beautiful and perfect, both externally and internally.

10 An Islamic work that both is perfect and perfecting will be produced when the writer equips himself with Islamic knowledge and knowledge of literature. Islamic knowledge should not only be basic but also be specific and deep, and should be applied in everyday life. (Shafie Abu Bakar, 1996, p. 30)

11 The final principle of the Takmilah Theory determines that a literary work should be able to reach the audience and should be suited to the requirements and priorities of Islamic literature. The aims of this final principle are to encourage audiences to become insan kamil, that is, to model themselves on the exemplary and honourable character of Prophet Muhammad (SAW).

12 The interpretations of the Qur'anic verses used is taken from Sahih International (The Holy Qur'an [1997]), available online at quran.com

13 The Takmilah Theory was introduced by Shafie Abu Bakar, a lecturer at the Malay Studies Department (JPM) of the Malaysian National University (UKM) in 1993. The emergence of this theory has paved the way for scholars and critics to analyse, comment on and critique literature based on Islamic principles. The Takmilah Theory emerged as a result of several papers presented discussing the theory and concepts of Islamic literature, beginning with a paper presented by Shafie Abu Bakar entitled "Sastera Islam: Teori Pengindahan dan Penyempurnaan dalam Rangka Tauhid" ["Islamic Literature: A Theory of Beautification and Perfection Within the Parameters of Tawhid'] in Port Dickson from 29 to 31 October, 1992. 


\section{REFERENCES}

Abizai Abi. (1989). Seekor kelawar di kamar pengantin. Kuching: Gabungan Persatuan Penulis Sarawak.

Abizai Abi. (2010). Sang kelawar kesiangan. Serdang: Citra Kurnia Enterprise. Abizai Abi. (2011). Kitab rahsia. Kuala Lumpur: Dewan Bahasa dan Pustaka.

Abizai Abi. (2015). Kitab bahasa. Kuala Lumpur:Institut Terjemahan dan Buku Malaysia Berhad.

Abizai Abi. (2015). Membentuk elok di teluk esok. Kuala Lumpur: Dewan Bahasa dan Pustaka.

Al-Quran Al-Karim (Al Haramain 7 dalam 1). 2015. Seventh edition. Shah Alam: Karya Bestari Sdn.Bhd.

Alam yang hijau. (2007). Ampang: Pekan Ilmu.

Anak global: Antologi Teks Kesusasteraan Melayu Moden KBSM. (2009). Kuala

Lumpur: Dewan Bahasa dan Pustaka.

Antologi sasterawan 2005. (2005). Kuala Lumpur: Persatuan Penulis Nasional.

Kata. (2014). Jawa Barat: Penerbit Cipta Bagus Segara.

Abang Median. (2016). Menelusuri rahsia takmilah dalam Kitab Rahsia. Ruangan

Bahasa dan Sastera. Utusan Borneo.

Belati cinta Zulaikha. (2004). Utusan Publication \& Distributors Sdn. Bhd.

Caturangga (1999). Kuala Lumpur: Dewan Bahasa dan Pustaka.

Cetera '94 (1994). Kuala Lumpur: Dewan Bahasa dan Pusataka.

Dongeng itu kembara. (1990). Miri: Persatuan Penulis Utara Malaysia.

dunsastera.dbp.my

Emas tempawan. (2004). Kuala Lumpur: Dewan Bahasa dan Pustaka.

Gema membelah gema 13. (1994). Kuala Lumpur: Gapena.

Gema membelah gema 12. (1999). Seremban: Koperasi Penulis Negeri Sembilan.

Gema membelah gema 14. (2004). Kuala Lumpur: Gapena.

Gema membelah gema 15. (2007). Kuala Lumpur: Gapena.

http://roslanjomel.blogspot.com/2012/serba-ringkas-tentang kepenyairan

Ja'afar Haji Hamdan (2013) Menekuni Imej Kelawar dalam Sinar Benar Menerusi

Nazrah Stilistik. Ruangan Bahasa dan Sastera. Utusan Borneo.

Jong Chian Lai (comp.). (1997). Menganyam kedukaan. Petaling Jaya: Sasbadi

Sdn. Bhd.

Kota asas tamadun bangsa. (2002). Kuching: DBP Cawangan Sarawak.

Mengabdi lestari. (2009). Kuala Lumpur: Permodalan Nasional Berhad.

Nyanyian pulau-pulau. (2004). Kuala Lumpur: Dewan Bahasa dan Pustaka.

Nur Rassidah Utama. (2012). Microchiroptera dan Abizai: Satu Singkapan Ilmiah

melalui Nazrah Semiotik. Ruangan Bahasa dan Sastera. Utusan Borneo.

Pelagus. (2003). Kuching: Sarawak.

Penangkap rama-rama dan kelawar. (2005). Miri: Persatuan Penulis Utara

Sarawak. 
Perkasihan musim. (1992). Kuching: DBP Cawangan Sarawak. Peta seniman. (1998). Kota Kinabalu: DBP Cawangan Sabah.

Ratib seribu syair. (2005). Kuala Lumpur: Gapena.

Saie Driss. (1987). Randau di pulau. TP.

Sahih International (The Holy Qur'an). (1997). https://quran.com/

Sakinah Abu Bakar. Puisi Sebagai Jalur Komunikasi: Meneroka Pemikiran

Penyair Sarawak. Paper presented at the Balai Budaya of the Sarawak

Branch of Dewan Bahasa dan Pustaka on 10 September, 2007.

Satu perasmian: Antologi puisi sempena perasmian bangunan DBP Cawangan

Sarawak. (1992). Kuala Lumpur: Dewan Bahasa dan Pustaka.

Sejadah hijrah. (2005). Kuching: DBP Cawangan Sarawak.

Shafie Abu Bakar. (November 1996). Takmilah: Teori sastera Islam. Dewan

Sastera No. 11, Vol. 26.

Simfoni dari Utara. (1994). JA Communication \& Publication.

Syaamil al-Quran terjemah per kata (2007). Jakarta: Departemen Agama Republik Indonesia.

Wajah kita: Antologi karya penulis Sarawak. (2002). Kuala Lumpur: Dewan Bahasa dan Pustaka.

Zainal Abidin Suhaili. (2011). Sinar benar. Kuala Lumpur: Dewan Bahasa dan Pustaka.

Zainal Abidin Suhaili. (2010). Sang kelawar kesiangan: Kumpulan puisi pilihan Abizai. Kuala Lumpur: Penerbit Citra Kurnia Enterprise.

Zainal Abidin Suhaili. (2015). Kitab rahsia. Kuala Lumpur: ITBM.

Received: 23 February 2018

Accepted: 5 September 2018 